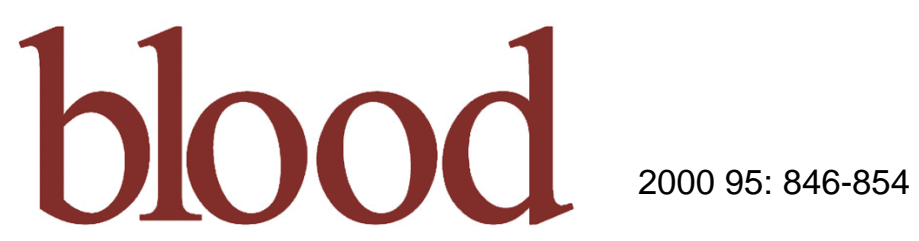

\title{
Opposing effects of engagement of integrins and stimulation of cytokine receptors on cell cycle progression of normal human hematopoietic progenitors
}

Yuehua Jiang, Felipe Prosper and Catherine M. Verfaillie

Updated information and services can be found at:

http://bloodjournal.hematologylibrary.org/cgi/content/full/95/3/846

Articles on similar topics may be found in the following Blood collections:

Hematopoiesis and Stem Cells (2715 articles)

Information about reproducing this article in parts or in its entirety may be found online at:

http://bloodjournal.hematologylibrary.org/misc/rights.dt|\#repub_requests

Information about ordering reprints may be found online at:

http://bloodjournal.hematologylibrary.org/misc/rights.dtl\#reprints

Information about subscriptions and ASH membership may be found online at:

http://bloodjournal.hematologylibrary.org/subscriptions/index.dtl

Blood (print ISSN 0006-4971, online ISSN 1528-0020), is published semimonthly by the American Society of Hematology, 1900 M St, NW, Suite 200, Washington DC 20036.

Copyright 2007 by The American Society of Hematology; all rights reserved.

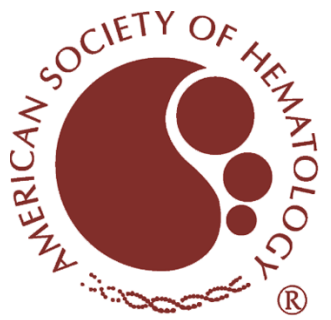




\title{
Opposing effects of engagement of integrins and stimulation of cytokine receptors on cell cycle progression of normal human hematopoietic progenitors
}

\author{
Yuehua Jiang, Felipe Prosper, and Catherine M. Verfaillie
}

We evaluated the effect of $\beta 1$-integrin receptor engagement on the expression and activity of cell cycle regulatory proteins in $\mathrm{CD}_{34}{ }^{+}$cells under conditions that mimic the steady-state marrow microenvironment and in the presence of supraphysiological concentrations of interleukin-3 (IL3) and stem cell factor (SCF). Adhesion of $\mathrm{CD}_{34}{ }^{+}$progenitors to fibronectin (FN) was similar whether IL3 or SCF was present or absent. Engagement of $\beta 1$-integrins blocked S-phase entry of $\mathrm{CD}^{+} 4^{+}$cells in the absence of IL3 or SCF, whereas addition of $10 \mathrm{ng} / \mathrm{mL}$ IL3 or SCF prevented such a block in S-phase entry. In the absence of IL3 or SCF, cyclin-E levels were significantly lower and p27 KIP1 levels significantly higher in $\mathrm{FN}$-adherent than in FN-nonadherent cells, or than in poly-L-lysine (PLL)-adherent or (PLL)nonadherent cells. Cyclin-dependentkinase (cdk)-2 activity was decreased and levels of cyclin-E-cdk2 complexes were lower in $\mathrm{FN}$-adherent than in PLL-adherent cells. In contrast, cyclin-E and p27 KIP1 protein levels and cdk2 activity in cells adherent to FN in the presence of IL3 or SCF were similar to those in PLL- adherent and FN-nonadherent or PLLnonadherent cells. In conclusion, under physiological cytokine conditions, integrin engagement prevents S-phase entrance of $\mathrm{CD}_{3}{ }^{+}$cells, which is associated with elevated levels of the contactdependent cyclin kinase inhibitor p27 ${ }^{\mathrm{KIP}}$. Supraphysiological concentrations of IL3 or SCF prevent $\mathrm{p} 27^{\mathrm{KIP} 1}$ elevation and override the integrin-mediated inhibition of entry into S phase. (Blood. 2000;95:846854)

(1) 2000 by The American Society of Hematology

\section{Introduction}

$\beta 1$-integrins on human $\mathrm{CD} 4^{+}$cells are responsible for their adhesion to fibronectin (FN) and to vascular cell adhesion molecules. ${ }^{1-3}$ In addition, a number of studies from our laboratory have shown that adhesion of normal human $\mathrm{CD} 34^{+}$colony-forming cells (CFC) to FN or direct engagement of $\beta 1$-integrins on $\mathrm{CD} 34^{+}$ cells with adhesion-blocking antibodies prevents CFC from entering the $\mathrm{S}$ phase of the cell cycle and inhibits expansion of CFC and more primitive long-term culture initiating cells (LTC-IC) in long-term bone marrow (BM) cultures. ${ }^{4-7}$ The mechanism through which engagement of $\beta 1$-integrins inhibits $\mathrm{CD}^{+} 4^{+}$progenitor proliferation is not known.

Integrin-mediated signaling has been extensively studied in cells of mesenchymal origin and in platelets. ${ }^{8-15}$ Integrins are divalent cation-dependent cell surface glycoproteins consisting of an $\alpha$ and a $\beta$ chain. They are responsible for cell-extracellular matrix (ECM) and cell-cell adhesion events. Integrins have a large, heterodimeric extracellular domain responsible for ligand recognition and binding, a short transmembrane domain, and a short cytoplasmic tail. The cytoplasmic tails of integrins have no intrinsic kinase activity. However, engagement of integrins results in the assembly of focal contacts in which a number of kinases become activated. ${ }^{8-15}$ Integrins activate the focal adhesion kinase (Fak) or the related kinase, Pyk-2. ${ }^{16,17}$ Phosphorylated Fak or Pyk-2 serve to bind and activate a number of Rous sarcoma (Src)homology domain SH2- and SH3-containing adaptor proteins,

From the Stem Cell Laboratory and Division of Hematology, Oncology and Transplantation, Department of Medicine and Cancer Center, University of Minnesota, Minneapolis, MN, and the Department of Hematology and Medical Oncology, Hospital Clinico Universitario, University of Valencia, Valencia, Spain.

Submitted July 6, 1999; accepted September 26, 1999.

Supported in part through grants from the National Institutes of Health (RO1 HL-49930 and RO1-DK-53673) and the Bone Marrow Transplant Research Fund to C. M. V. and a grant from Fondo De Investigaciones Sanitarias(FIS 98/0863) to F.P. C. M. V. is a scholar of the Leukemia Society of America. including Src, paxillin, CrkL, Grb-2, p130 Cas, $\mathrm{p} 120^{\mathrm{Cbl}}$, and the $\mathrm{p} 85$ subunit of phospho-inositol-3 kinase. ${ }^{18-24}$ Although the exact mechanism or mechanisms through which engagement of integrins affects cell proliferation, differentiation, or survival are not known, integrins can activate the phospho-inositol-3-kinase pathway ${ }^{23}$ and the Ras/mitogen-activated protein kinase pathway, ${ }^{24}$ both of which mediate signals regulating growth. Further, integrin engagement induces immediate-early inflammatory response genes. ${ }^{24}$

Growth of adherent cells such as fibroblast requires signals not only from growth factor receptors but also from integrins. ${ }^{13-15,25}$ Recent studies have shown that integrin-mediated adhesion of fibroblasts is associated with increased levels of cyclin- $\mathrm{D}_{1}$, leading to hyperphosphorylation of the retinoblastoma protein $(\mathrm{Rb})$ and transition of the cell through the restriction-point $(R)$ in the $G_{1} / S$ phase of the cell cycle. ${ }^{26,27}$ Other studies have shown that adhesion of fibroblasts to ECM also results in up-regulation of cyclin-E/cdk2 activity owing to decreases in the cdki's p $21^{\mathrm{CIP} 1}$ and $\mathrm{p} 27^{\mathrm{KIP} 1}$, and up-regulation of cyclin-A levels. ${ }^{26,27}$ It is not known whether or how these observations made in mesenchymal cells relate to signals emanating from integrins following their engagement on human hematopoietic progenitors, which are nonadherent cells.

Signals initiated by integrins can be modified or enhanced by costimulation of cells with cytokines or growth factors. ${ }^{15}$ In the hematopoietic system, a number of investigators have examined the effect of cytokine stimulation on integrin-mediated adhe-

Y. J. and F. P. contributed equally to this paper.

Reprints: Catherine M. Verfaillie, Box 806 UMHC, 420 Delaware St SE, Minneapolis, MN 55455; e-mail: verfa001@tc.umn.edu.

The publication costs of this article were defrayed in part by page charge payment. Therefore, and solely to indicate this fact, this article is hereby marked "advertisement" in accordance with 18 U.S.C. section 1734.

(C) 2000 by The American Society of Hematology 
From www.bloodjournal.org at kuleuven on October 6, 2010. For personal use only.

sion. ${ }^{28-34}$ Cytokines, including interleukin 3 (IL3), granulocytemacrophage (GM)-colony stimulating factor (CSF), and stem cell factor (SCF), may increase at least short-term integrin-mediated adhesion of cytokine-starved $\mathrm{CD} 34^{+}$to FN. Other studies show that IL3 or SCF do not affect adhesion of progenitor cells. Another group of reports has demonstrated a synergistic effect of cytokines and FN on the expansion of progenitors when cultured in the absence of stromal feeders, thus linking signals initiated following integrin and cytokine receptor stimulation.

In this study, we show that engagement of $\beta 1$-integrins on normal human $\mathrm{CD} 34^{+}$progenitors results in the inhibition of S-phase entry/progression and increased levels of the cyclin-kinase inhibitor $\mathrm{p} 27^{\mathrm{KIP} 1}$, which inhibits cyclin-E-cdk2 complex formation and cdk2 activity. However, costimulation of cells with cytokines, such as IL3 or SCF, prevents accumulation of p2 $7^{\mathrm{KIP} 1}$, leading to continued S-phase entry/progression in progenitors even though they are adherent to FN.

\section{Materials and methods}

We obtained antibodies and reagents from various sources. Human plasma FN was purified as a by-product of Factor VIII. Poly-L-lysine (PLL) and bovine serum albumin (BSA; 98\%) were purchased from Sigma Chemical Co (St. Louis, MO).

Blocking antibodies against the integrins $\alpha 4$ (P4C2), $\alpha 5$ (P1D6), $\beta 1$ (P4C10), and $\alpha 2$ (P1E6) were purchased from Gibco-BRL (Grand Island, NY). The activating anti- $\beta 1$-antibody, $8 \mathrm{~A} 2$, was a kind gift from Dr Kovach, University of Washington (Seattle, WA). ${ }^{35}$ Antibodies against CD34 and CD62L were purchased from Becton Dickinson (Mountain View, $\mathrm{CA}$ ), and mouse immunoglobulin $\mathrm{G}$ (IgG) was purchased from Sigma. FITC-conjugated goat antimouse antibody was obtained from Biosource International, Camarillo, CA.

For the flow-cytometric assessment of the cell cycle, unconjugated antibodies against $\mathrm{p} 21^{\mathrm{CIP} 1}, \mathrm{p} 27^{\mathrm{KIP} 1}, \mathrm{p} 16^{\mathrm{INK} 4 \mathrm{~A}}$, and cyclin-E and fluorescein (FITC)-conjugated antibodies against cyclin-A and cyclin- $\mathrm{D}_{1+2+3}$ were obtained from Pharmingen Inc (San Diego, CA). FITC-coupled anti-PCNA antibodies were obtained from DAKO Inc. Secondary goat antimouse FITC antibodies as well as isotype-control antibodies were also purchased from Pharmingen Inc.

For use in immunoprecipitation and Western blot, antibodies against $\mathrm{p} 21^{\mathrm{CIP} 1}, \mathrm{p} 27^{\mathrm{KIP} 1}$, Cyclin-E, Cdk2, and $\beta$-actin were obtained from Pharmingen Inc. Secondary goat antimouse horseradish peroxydase (HRP)conjugated antibodies were obtained from Pharmingen Inc.

The following cytokines were purchased from R\&D Systems (Minneapolis, MN): IL3, IL6, leukemia inhibitory factor (LIF), and macrophageinflammatory protein (MIP)-1 $\alpha$. SCF was a kind gift from Amgen Inc (Thousand Oaks, CA); fetal liver tyrosine kinase-3 ligand (Flt3-L) was a kind gift from Immunex Inc (Seattle, WA). GM-CSF was purchased from Immunex, and erythropoietin and G-CSF were purchased from Amgen.

We obtained $50 \mathrm{~mL}$ of heparinized $\mathrm{BM}$ from normal donors under steady-state conditions. To obtain mobilized peripheral blood (PB) progenitors, we selected normal donors using the standard criteria of the American Association of Blood Banks for blood donors. The donors received a daily dose of $10 \mu \mathrm{g} / \mathrm{kg} / \mathrm{d}$ G-CSF subcutaneous for 5 days. On day 6 donors underwent an apheresis procedure, as previously described. ${ }^{36}$ All donors signed an informed consent according to the guidelines from the Committee for the Protection of Human Subjects at the University of Minnesota.

Steady-state BM- and G-CSF-mobilized PB mononuclear cells were separated by Ficoll Hypaque centrifugation (specific gravity, 1077) (Sigma). $\mathrm{CD}_{4}{ }^{+}$cells were selected either by 2 passages over the MACS CD34 Isolation Kit (Miltenyi Biotec, Sunnyvale, CA) or by sequential selection with the Ceprate SC device for clinical scale stem cell concentration (CellPro, Bhotell, WA) followed by the MACS CD34 Isolation Kit. ${ }^{36}$ CD $34^{+}$populations were more than $95 \%$ pure.
As a low-dose cytokine, serum-free medium, we used Iscove's Modified Dulbecco's Medium (IMDM, Gibco) containing $20 \mathrm{mg} / \mathrm{mL}$ BSA, 10 $\mu \mathrm{g} / \mathrm{mL}$ insulin (Sigma), $200 \mu \mathrm{g} / \mathrm{mL}$ transferrin (Sigma), 10-4 mol/L 2-mercapto-ethanol (Bio-Rad, Hercules, CA), $100 \mathrm{U} / \mathrm{mL}$ penicillin and $100 \mathrm{U} / \mathrm{mL}$ streptomycin (Gibco), and the following cytokines ${ }^{37}: 200 \mathrm{pg} / \mathrm{mL}$ GM-CSF, $1000 \mathrm{pg} / \mathrm{mL}$ G-CSF, 200 pg/mL SCF, 50 pg/mL LIF, 200 pg/mL MIP- $1 \alpha$, and $1000 \mathrm{pg} / \mathrm{mL}$ IL-6.

Integrins were engaged in two ways. One way was to cause them to adhere to FN. In this method, $\mathrm{CD} 34^{+}$cells suspended in serum-free IMDM with or without cytokines were plated onto wells coated with $100 \mu \mathrm{g} / \mathrm{mLFN}$ or $10 \mu \mathrm{g} / \mathrm{mL}$ PLL in a humidified atmosphere at $37^{\circ} \mathrm{C} ., 5,7$ Adherent and nonadherent cells were collected after 2 hours to assess adhesion and at 12 to 16 hours to assess cell cycle status as described. ${ }^{3,5,7}$

Integrins were also engaged in solution. In this method, $\mathrm{CD} 34^{+}$cells were incubated in IMDM, with or without cytokines and with adhesionblocking antibodies against the $\beta 1-, \alpha 2-, \alpha 4$ - and $\alpha 5$-integrins, CD62L (all at $10 \mu \mathrm{g} / \mathrm{mL}$ ), or mouse $\mathrm{IgG}$ control for 30 minutes at $37^{\circ} \mathrm{C} .{ }^{7}$ Cells were washed and incubated with goat antimouse antibody (1:500 dilution) for 8 to 12 hours at $37^{\circ} \mathrm{C}$ in a humidified atmosphere.

We assessed cell adhesion in two ways. In the ${ }^{51} \mathrm{Cr}$ labeled adhesion assay, CD34+ cells were labeled with $0.1 \mathrm{mCi}{ }^{51} \mathrm{Cr}$ (specific activity 734.5 $\mathrm{mCi} / \mathrm{mg}$; NEN, Boston, MA) for 1 hour at $37^{\circ} \mathrm{C}$ and washed twice. ${ }^{51} \mathrm{Cr}$-labeled CD $34^{+}$cells suspended in IMDM with or without cytokines were plated in ligand-coated dishes for 2 hours. Nonadherent cells were collected. Adherent cells were lysed with triton-X-100 (Sigma), wells were harvested, and ${ }^{51} \mathrm{Cr}$ emission was counted with the use of a Gamma 4000 Counting System (Beckman Instruments, Irvine, CA) ${ }^{37}$ The percentage of adhesion was calculated as follows: $\%=(\mathrm{cpm}$ emission in adherent cells - cpm background $) \div($ cpm emission in all cells - cpm background) $\times 100$.

We also assessed cells for adherence to CFC. In this method, CD34 ${ }^{+}$ cells incubated in IMDM with or without cytokines were plated in ligand-coated dishes for 2 hours. Nonadherent cells were collected in 3 washes, as described. ${ }^{3,5}$ Adherent cells were collected after trypsinization for 7 minutes. The percentage of adhesion of CFC was determined by replating adherent and nonadherent $\mathrm{CD} 34^{+}$cells in methylcellulose assay and enumerating CFC in the adherent and nonadherent portion. ${ }^{3,5}$ The percentage of adhesion was determined as follows: $\%$ adhesion $=(\mathrm{CFC}$ in adherent cells $) \div($ CFC in adherent + nonadherent portion $) \times 100$.

We performed various procedures to assess cell cycle and cell cycle regulatory elements. A flow-cytometric evaluation of cell cycle ${ }^{38}$ was performed in the following way: $\mathrm{CD} 34^{+}$cells incubated in IMDM with or without cytokines were plated in ligand-coated dishes for 12 to 16 hours. Nonadherent cells were collected in 3 washes, as described. ${ }^{3,5}$ Adherent cells were collected after trypsinization for 7 minutes. We have previously shown that trypsin does not affect assessment of cell cycle. ${ }^{5}$ Freshly collected $\mathrm{CD} 34^{+}$cells or adherent or nonadherent $\mathrm{CD} 34^{+}$cells recovered after 12 hours of adhesion to BSA, PLL, or FN were fixed in $75 \%$ ethanol and stained with propidium iodide $(50 \mu \mathrm{g} / \mathrm{mL}$ propidium iodide $\Sigma$, and 10 $\mu \mathrm{g} / \mathrm{mL}$ RNase $\Sigma$ in phosphate buffer saline (PBS) [Gibco]). ${ }^{39}$ Cells were analyzed with a FACS-Calibur flow cytometer (Becton Dickinson). Cell cycle phase distribution was calculated with the use of ModFit LT software (Verity Software House Inc). In some experiments, CD34 ${ }^{+}$cells selected from G-CSF-mobilized PB were cocultured with BSA, FN, or PLL in the presence of low-dose cytokines with or without IL3 or SCF. After 60 hours, cell cycle status was evaluated by fluorescence-activated cell sorter (FACS).

Flow cytometric evaluation of cell cycle proteins was performed as follows: $\mathrm{CD} 34^{+}$cells recovered in the adherent and nonadherent portion of adhesion assays were fixed in $75 \%$ ethanol, then incubated overnight at $-20^{\circ} \mathrm{C} .{ }^{40}$ For assessment of cyclin-D, cells were fixed in $1 \%$ formaldehyde (Sigma) for 15 minutes before fixation in ethanol. Cells were washed and permeabilized with $0.15 \%$ Triton X-100 (Sigma) for 5 minutes, washed, and then incubated with antibodies directed at PCNA, cyclin- $\mathrm{D}_{1+2+3}$, cyclin-E, cyclin-A, p16 ${ }^{\mathrm{INK} 4 \mathrm{~A}}, \mathrm{p} 21^{\mathrm{CIP} 1}$, and $\mathrm{p} 27^{\mathrm{KIP} 1}$ or with isotype control antibody at room temperature for 30 minutes. When unconjugated antibodies were used, cells were washed and incubated with FITC-conjugated goat antimouse Ig for 30 minutes in the dark. Cells were washed and 
resuspended in $50 \mu \mathrm{g} / \mathrm{mL}$ propidium iodide. Cells were analyzed with a FACS-Calibur flow cytometer with the use of Cell Quest and ModFit LT software. In some experiments, CD34+ cells selected from G-CSFmobilized PB, which had not been cultured with low doses of cytokines to induce cell proliferation, were cocultured with FN or PLL in the presence of low-dose cytokines with or without IL3 or SCF. After 60 hours, levels of p2 $7^{\mathrm{KIP} 1}$ were assessed by FACS and Western blot.

A thymidine suicide assay was performed as follows: CFC proliferation was assessed in ${ }^{3} \mathrm{H}$-thymidine suicide assays as described. ${ }^{5,7}$ (1) Adherent and nonadherent $\mathrm{CD} 34^{+}$cells recovered after 12-hour adhesion to BSA, PLL, or FN or (2) $\mathrm{CD} 34^{+}$cells incubated with blocking or nonblocking anti-integrin antibodies or control antibodies for 12 hours were incubated at $37^{\circ} \mathrm{C}$ in serum-free IMDM for 30 minutes with or without $5 \mathrm{mCi}{ }^{3} \mathrm{H}$ thymidine (specific activity, $6.7 \mathrm{Ci} / \mathrm{mmol}, \mathrm{NEN}$ ), washed with excess cold thymidine $(500 \mathrm{mg} / \mathrm{mL} \Sigma$ in IMDM plus $20 \%$ FCS), and plated in methylcellulose assays. The percentage of $\mathrm{CFC}$ in $\mathrm{S}$ phase was calculated as follows: $\% \quad \mathrm{CFC}$ in S-phase $=\left[\right.$ (number of CFC without ${ }^{3} \mathrm{H}-$ thymidine - Number of $\mathrm{CFC}$ with ${ }^{3} \mathrm{H}$-thymidine $\left.) \times 100\right] \div$ [number of $\mathrm{CFC}$ without ${ }^{3} \mathrm{H}$-thymidine].

In Western blotting and immunoprecipitation, ${ }^{39}$ cells recovered in the adherent and nonadherent portion of adhesion assay were lysed in NP-40 lysis buffer $(50 \mathrm{mmol} / \mathrm{L}$ Tris $\mathrm{HCl}, \mathrm{pH} 7.4,250 \mathrm{mmol} / \mathrm{L} \mathrm{NaCl}, 2 \mathrm{mmol} / \mathrm{L}$ ethylenediaminetetraacetic acid, $1 \%$ NP-40, $1 \mathrm{mmol} / \mathrm{L}$ phenylmethylsulfonyl fluoride (PMSF), $10 \mu \mathrm{g} / \mathrm{mL}$ aprotinin, $10 \mu \mathrm{g} / \mathrm{mL}$ leupeptin, 50 $\mathrm{mmol} / \mathrm{L} \mathrm{NaFl}, 0.1 \mathrm{mmol} / \mathrm{L} \mathrm{Na}_{3} \mathrm{VO}_{4}$, all from Sigma), and lysates were recovered by centrifugation. Total protein from each sample to be used in Western blots or immunoprecipitations was normalized with the use of the Bradford assay.

In Western blotting, protein lysates from more than $2 \times 10^{6}$ adherent, nonadherent, or unmanipulated cells were separated by sodium dodecyl sulfate-polyacrylamide gel electrophoresis (SDS-PAGE) and transferred onto nitrocellulose with the use of a Semidry Transfer Apparatus (Bio-Rad). Immunoblots were blocked in freshly prepared TBS (Pierce, Rockford, IL) containing 5\% nonfat dry milk. Blots were incubated with $1 \mathrm{ng} / \mathrm{mL}$ primary antibody in blocking buffer for 2 hours at room temperature. After 4 washes in TBST (TBS supplemented with $0.05 \%$ Tween 20), blots were incubated for 1 hour with a goat antimouse HRP-conjugated antibody (1:10 000 dilution). Bands were visualized with the use of an ECL detection system (E.I. du Pont de Nemours \& Co, Boston, MA). Quantitative differences in protein levels in different conditions were evaluated by scanning images with a GS-700 Imaging Densitometer (Bio-Rad); the images were then quantitated with the use of Molecular Analyst software (Bio-Rad).

In immunoprecipitation, protein lysates were precleared with $50 \mu \mathrm{L}$ protein-G-agarose (Boehringer Mannheim, Indianapolis, IN) for at least 3 hours on a rocking platform, and nonbound material was recovered by centrifugation. We added $1 \mu \mathrm{g} / \mathrm{mL}$ anti-cyclin-E or anti-cdk2 antibody, and the mixture was gently rocked for at least 2 hours at $4^{\circ} \mathrm{C}$. Soluble immune complexes were incubated with $100 \mu \mathrm{L}$ protein-G-agarose beads for 3 hours and bead/protein complexes recovered by centrifugation. Beads were washed 3 times for 20 minutes with lysis buffer, and bound material was eluted by boiling in $1 \%$ SDS. The immune complexes were resolved by SDS-PAGE and blots probed as described above. Differences were evaluated with the use of a GS-700 Imaging Densitometer (Bio-Rad), and the images were then quantitated with the use of Molecular Analyst software.

A histone $\mathrm{H} 1$ kinase assay was performed as follows: Cdk2-associated kinase activity was assayed in cdk2- or cyclin-E-immune complexes. Cell lysates were prepared as described above, and cyclin-E or cdk2 was immunoprecipitated from similar quantities of protein. Bead/protein complexes were washed 3 times with lysis buffer and twice with kinase buffer (50 mmol/L Tris- $\mathrm{HCl}[\mathrm{pH} 7.5], 10 \mathrm{mmol} / \mathrm{L} \mathrm{MgCl}_{2}$, and $1 \mathrm{mmol} / \mathrm{L}$ dithiothreitol). Then, $5 \mu \mathrm{g}$ histone H1 (Boehringer Mannheim), $1 \mu \mathrm{M}$ ATP, and $10 \mu \mathrm{Ci}\left[\mathrm{r}^{32} \mathrm{P}\right]$ were added to the kinase buffer for 30 minutes at $30^{\circ} \mathrm{C}$. The reaction was stopped by adding Laemmli sample buffer and boiling for 3 minutes. Reaction products were resolved by SDS-PAGE. The gel was dried and exposed to X-ray film. Differences were evaluated by scanning images with the use of a GS-700 Imaging Densitometer (Bio-Rad); the images were then quantitated with the use of Molecular Analyst software.

Results of experimental points obtained from multiple experiments were reported as the mean \pm SEM. Significance levels were determined by a 2-sided Student $t$ test.

\section{Results}

\section{Cell cycle status of mobilized PB progenitors}

We have shown that $25 \%$ to $30 \%$ of CFC present in normal, steady-state BM are in S phase, ${ }^{5,7}$ and that entry in $\mathrm{S}$ phase is inhibited following coculture with $\mathrm{FN}^{5}$ or when $\beta 1$-integrins are engaged directly by adhesion-blocking antibodies. ${ }^{7}$ We now show that $95 \%$ to $99 \%$ of mobilized PB CFC and $\mathrm{CD}_{3} 4^{+}$are in $\mathrm{G}_{0} / \mathrm{G}_{1}$ $(n=5)$; this is consistent with other published reports. ${ }^{41,42}$ Culture for 48 hours with cytokines at concentrations found in the BM microenvironment (200 pg/mL GM-CSF, 1000 pg/mL G-CSF, 200 $\mathrm{pg} / \mathrm{mL}$ SCF, $50 \mathrm{pg} / \mathrm{mL}$ LIF, $200 \mathrm{pg} / \mathrm{mL}$ MIP-1 $1 \alpha$, and $1000 \mathrm{pg} / \mathrm{mL}$ IL-6) ${ }^{37}$ caused $23 \pm 3 \%$ of mobilized PB CD34+ cells $(n=4)$ and $29 \pm 4 \%$ of mobilized PB CFC $(n=14)$ to enter $S$ phase. We then evaluated whether G-CSF-mobilized $\mathrm{PB} \mathrm{CD}^{+} 4^{+}$cells undergo similar adhesion-mediated proliferation inhibition as $\mathrm{CD}^{+} 4^{+}$cells in steady-state BM.

In a first set of experiments, $\mathrm{CD} 34^{+}$cells were induced to proliferate by culturing in low doses of cytokines for 48 to 72 hours. Cultured PB CD34+ ${ }^{+}$cells were then plated for 12 hours in FN-, BSA-, or PLL-coated wells. We have previously shown that although mobilized PB CD $34^{+}$cells express fewer $\alpha 4 \beta 1$ integrins, and therefore interact less well with fibronectin, expression of $\alpha 4 \beta 1$ increases to normal levels after 24-to-48-hour culture with cytokines ex vivo. Coculture with FN, but not with BSA or PLL, resulted in a significant decrease in the portion of $\mathrm{CFC}(8.5 \pm 3 \%)$ (Figure 1A) and CD34+ cells $(11.5 \% \pm 2 \%)$ (Figure 1B) adherent to $\mathrm{FN}$ in $\mathrm{S}$ phase. Several observations indicate that this is not due to selective adhesion of $\mathrm{G}_{0} / \mathrm{G}_{1}$ cells: (1) The percentage of CFC in $\mathrm{S}$ phase in the adherent and the nonadherent populations combined was significantly lower for cells cocultured with FN than for cells cultured with either BSA or PLL; (2) Incubation of CD34 ${ }^{+}$cells with the $\beta 1$-integrin-activating antibody $8 \mathrm{~A} 2$ increased $\mathrm{CD} 34^{+}$ cell adhesion (without $8 \mathrm{~A} 2,10 \pm 1 \%$; with $8 \mathrm{~A} 2,40 \pm 1.4 \%$ ). The cell cycle status of $\mathrm{CD}_{3} 4^{+}$cells present in the $\mathrm{FN}$-adherent and FN-nonadherent portions of assays performed in the presence or absence of $8 \mathrm{~A} 2$ was, however, equivalent (FN-adherent $\mathrm{CD} 34^{+}$ cells: without $8 \mathrm{~A} 2=11 \pm 3 \%$ S-phase, $\mathrm{n}=3$; with $8 \mathrm{~A} 2=11.5 \pm$ $1.6 \% \mathrm{~S}$ phase, $\mathrm{n}=9$; $\mathrm{FN}$-nonadherent $\mathrm{CD} 34^{+}$cells: without $8 \mathrm{~A} 2=21 \pm 4 \% \mathrm{~S}$ phase, $\mathrm{n}=3$; with $8 \mathrm{~A} 2=22.5 \pm 2 \% \mathrm{~S}$ phase, $\mathrm{n}=9$ ); (3) Engagement of $\beta 1$-integrins ( $\pm 2.4 \% \mathrm{~S}$ phase), $\alpha 5$-integrins ( $10 \pm 5.8 \% \mathrm{~S}$ phase), and $\alpha 4$-integrins (10.5 $\pm 6.8 \%$ $\mathrm{S}$ phase), but not the $\alpha 2$-integrin or CD62L, with adhesionblocking antibodies and cross-linking with a secondary goat antimouse antibody decreased the portion of $\mathrm{CFC}$ in $\mathrm{S}$ phase (Figure 2). Although the portion of CFC exposed to anti- $\alpha 4-b$ anti$\alpha 5-\mathrm{b}$ or anti- $\beta 1$-integrin antibodies and $\mathrm{FN}$-adherent $\mathrm{CFC}$ that were in $\mathrm{S}$ phase was similar, the percentage of CFC cultured in FN-coated wells in $\mathrm{S}$ phase (ie, in FN-adherent plus FNnonadherent portions) was higher than in antibody-exposed CFC. This is consistent with the fact that most CD $34^{+}$cells express $\beta 1$-integrins, and antibody-mediated engagement of $\beta 1$ therefore suppresses S-phase entry in the majority of cells, whereas only 
A
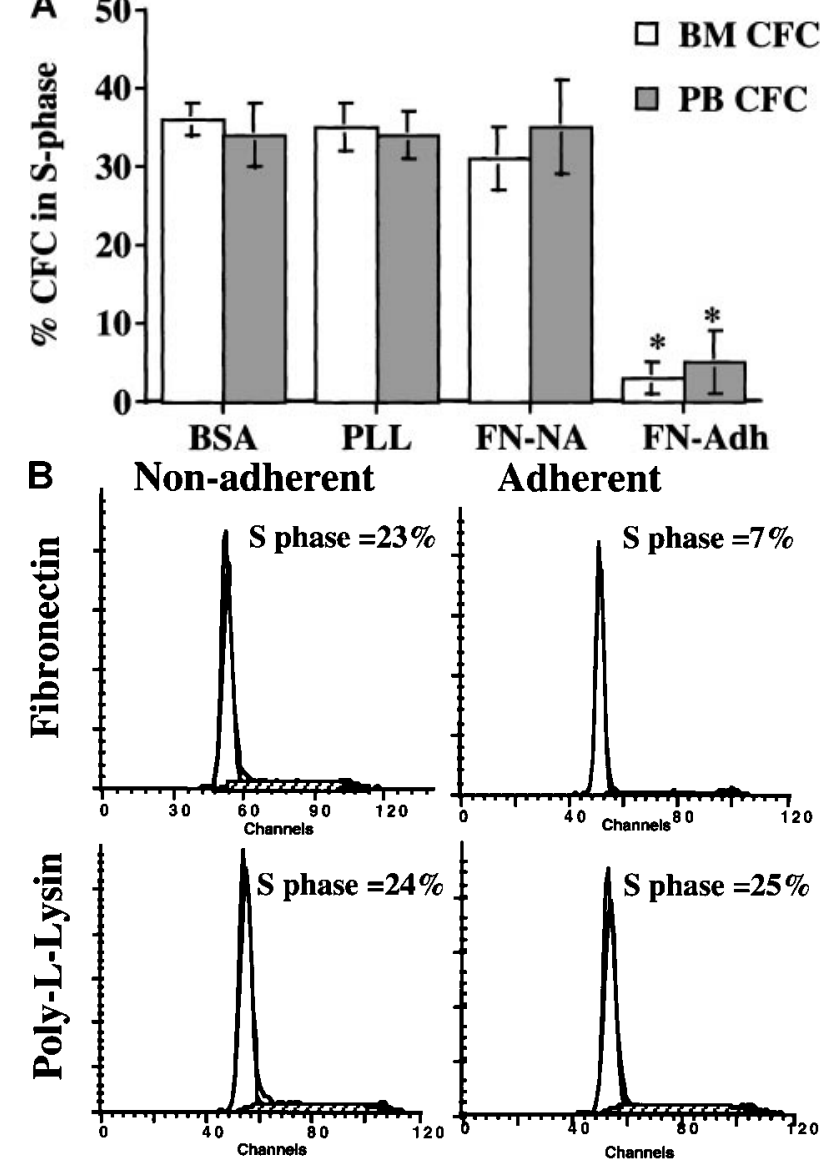

Figure 1. Adhesion to FN. Adhesion to FN decreases portion of blood and BM $\mathrm{CD} 34^{+}$cells and CFC that are in S phase. $\mathrm{CD}_{4} 4^{+}$cells from steady-state BM or mobilized PB were cultured for 48 hours in serum-free medium with low-dose cytokines. Cells were then plated in wells coated with PLL or FN for 12 to 16 hours. We collected adherent (Adh) and nonadherent (NA) cells separately. We analyzed the $S$ phase of CFC by thymidine suicide assay and analyzed the $S$ phase of all $\mathrm{CD}_{3}{ }^{+}$cells by labeling cells with propidium iodide and analysis by FACS. (A) Thymidine suicide assay ( $n=4$ for BM and $n=4$ for PB). Data are shown as mean \pm SEM. Comparison between the FN-Adh and the FN-NA portion for PB or BM: ${ }^{*}=P<.01$. (B) FACS analysis of propidium iodide labeled cells $(n=12)$. A representative experiment is shown.

$10 \%$ to $15 \%$ adhere to $\mathrm{FN}$ in the absence of $8 \mathrm{~A} 2$. Adhesion via $\beta 1$-integrins therefore inhibits cell cycle progression in the adherent portion only. Thus, these studies are consistent with the concept that block in cell cycle progression in FN-adherent cells is caused by engagement of integrins by $\mathrm{FN}$ and not by selective adhesion of $\mathrm{G}_{0} / \mathrm{G}_{1}$ cells.

To confirm this further, we tested the hypothesis that culture of freshly isolated PB CD $34^{+}$cells, which are in $\mathrm{G}_{0} / \mathrm{G}_{1}$, on $\mathrm{FN}$ rather than on BSA- or PLL-containing wells would delay entry of $\mathrm{CD}_{3}{ }^{+}$cells into $\mathrm{S}$ phase (Figure 3 ). Freshly sorted CD34 ${ }^{+}$cells $(\mathrm{n}=2)$ suspended in low-dose cytokine-containing serum-free medium were cultured in wells coated with FN or PLL. After 24, 48, and 60 hours, adherent and nonadherent cells were collected, and cell cycle status was assessed by FACS. On day $0,0.9 \%$ and $1 \%$ of $\mathrm{CD}_{3} 4^{+}$cells were in $\mathrm{S}$ phase. For PLL-adherent cells, this increased to $5 \%$ and $3 \%$ after 24 hours, to $17 \%$ and $12 \%$ after 48 hours, and to $17 \%$ and $16 \%$ after 60 hours. For cells in the FN-nonadherent $\mathrm{CD} 34^{+}$cell portion, $6 \%$ and $4 \%$ were in $\mathrm{S}$ phase after 24 hours, $17 \%$ and $13 \%$ after 48 hours, and $18 \%$ and $16 \%$

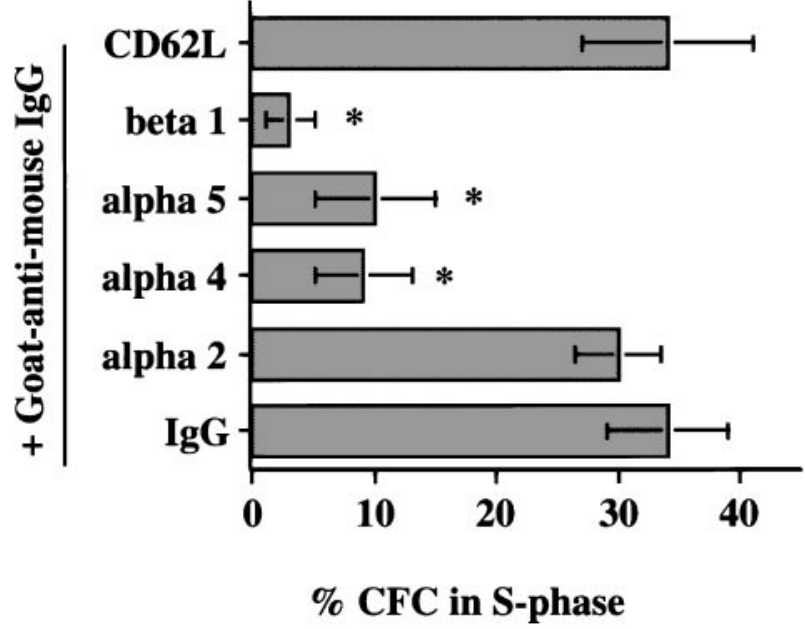

Figure 2. Antibody-mediated engagement of $\beta 1$-integrins. Antibody-mediated engagement of $\beta 1$-integrins inhibits S-phase entry of cultured blood CFC. Mobilized PB CD $34^{+}$cells cultured for 48 hours in serum-free medium with low-dose cytokines were incubated with adhesion-blocking antibodies against the $\alpha 2(n=3), \alpha 4(n=6)$, $\alpha 5(n=5)$, or $\beta 1(n=6)$ integrins or CD62L $(n=3)$ or mouse IgG $(n=6)$. After incubation for 30 minutes at $4^{\circ} \mathrm{C}$, cells were washed and incubated with goat antimouse antibody. Cells were incubated for 8 to 12 hours at $37^{\circ} \mathrm{C}$, and the percentage of CFC in S phase was assessed by thymidine suicide assay. Data are shown as the mean \pm SEM. Comparison between anti- $\beta 1$, anti- $\alpha 4 \mathrm{~b}$ and anti$\alpha 5$ group and IgG control group: ${ }^{*}=P<.01$.

after 60 hours. In contrast, for $\mathrm{CD}^{+} 4^{+}$cells present in the $\mathrm{FN}$-adherent portion, only $3 \%$ and $2 \%$ were in $\mathrm{S}$ phase after 24 hours, $7 \%$ and $4 \%$ after 48 hours, and $10 \%$ and $4 \%$ after 60 hours. This confirms that contact with FN prevents S-phase entry.

\section{$\mathrm{G}_{1} / \mathrm{S}$ blockade is associated with increased} p27 ${ }^{\mathrm{KIP} 1}$ levels but decreased cyclin-E protein levels and decreased cdk2 kinase activity

We next examined the effect of adhesion to $\mathrm{FN}$ on cell cycle protein expression and activity. CD $34^{+}$cells were plated for 48 to 72 hours in low-dose cytokine-containing medium to induce entry of cells into $\mathrm{S}$ phase. Cells were then plated in dishes coated with $\mathrm{FN}$ or PLL for 12 to 16 hours, and adherent and nonadherent cells were collected separately, permeabilized, and stained with antibodies directed at cell cycle-associated proteins. Since no significant differences were seen in the cell cycle status of cells assayed in the presence (FN-adherent: $11.4 \pm 3.1 \% \mathrm{~S}$ phase; FN-nonadherent: $26.7 \pm 4.9 \% \mathrm{~S}$ phase, $\mathrm{n}=3$ ) or absence of low-dose cytokines

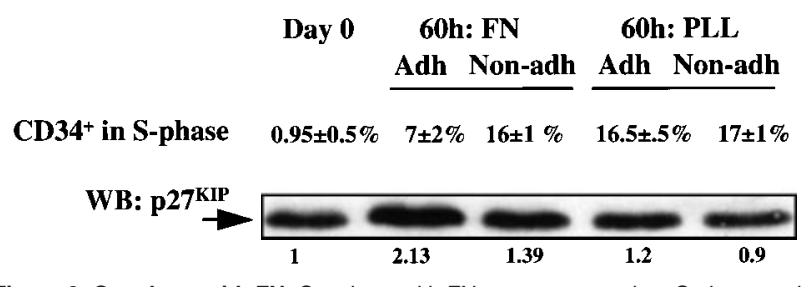

Figure 3. Coculture with FN. Coculture with FN prevents entry into $S$ phase and is associated with elevated $\mathrm{p} 27^{\mathrm{KIP} 1}$ levels. G-CSF-mobilized PB $\mathrm{CD} 34^{+}$cells were analyzed fresh or after coculture with FN or PLL for 60 hours in the presence of serum-free medium supplemented with low concentrations of cytokines. Adherent and nonadherent cells were collected separately and labeled with propidium iodide (FACS analysis cell cycle status, $n=3$ ) or subjected to Western blot (representative example of 2 experiments; levels of $\mathrm{p} 27^{\mathrm{KIP} 1}$ ) as described in "Materials and methods." Quantitative differences in protein levels were evaluated by scanning images with the use of a GS-700 Imaging Densitometer, and the images were quantitated using Molecular Analyst software. Values under Western blot represent relative density of each band compared with day 0 levels of $\mathrm{p} 27^{\mathrm{KIP}}$. 
(FN-adherent: $11.5 \pm 2 \% \mathrm{~S}$ phase; FN-nonadherent: $22.5 \pm 2.3 \%$ $\mathrm{S}$ phase, $\mathrm{n}=9$ ), or in the presence or absence of the activating antibody $8 \mathrm{~A} 2$ (see above), results from assays with or without $8 \mathrm{~A} 2$ or with or without low-dose cytokines during the adhesion assay were pooled.

Cyclin-E protein levels were lower in $\mathrm{FN}$-adherent compared with FN-nonadherent cells, and FN-adherent cells had elevated levels of p27 ${ }^{\mathrm{KIP} 1}$ compared with FN-nonadherent cells (Figure 4, representative example of 5 individual experiments). FN-adherent cells contained slightly less cyclin-A than FN-nonadherent cells, and levels of PCNA, cyclin- $\mathrm{D}_{1+2+3}, \mathrm{p} 16^{\mathrm{INK} 4 \mathrm{~A}}$, and $\mathrm{p} 21^{\mathrm{CIP} 1}$ were similar in $\mathrm{FN}$-adherent and FN-nonadherent cells (not shown). These results were confirmed by immunoprecipitation and Western blot. All blots were analyzed by densitometry to obtain quantitative results. Levels of $\mathrm{p} 27^{\mathrm{KIP} 1}$ were $1.99 \pm 0.1$-fold higher $(P<.01)$ in FN-adherent compared with FN-nonadherent cells (Figure 5, representative experiment of 3 individual experiments). Levels of cyclin-E were $4.4 \pm 0.9$-fold lower in $\mathrm{FN}$-adherent compared with FN-nonadherent cells (Figure 5). We also immunoprecipitated cdk2 from $\mathrm{FN}$-adherent and FN-nonadherent cells. Immunoprecipitates were then evaluated for the amount of cdk2 present and the activity of the kinase. In FN-adherent cells, cdk2 activity was $3.46 \pm 0.16$ lower than in FN-nonadherent cells (Figure 5). However, the total cdk2-protein level was not significantly different between FN-adherent and FN-nonadherent cells (Figure 5). Further, the amount of cdk2 that coimmunoprecipitated with cyclin-E was $3.8 \pm 0.25$-fold lower in $\mathrm{FN}$-adherent than FN-nonadherent cells (not shown). No differences between cells that were adherent or nonadherent to PLL were seen in PCNA, cyclin- $\mathrm{D}_{1+2}+3$, cyclin-E, cyclin-A, cdk2, p16 ${ }^{\mathrm{INK} 4 \mathrm{~A}}, \mathrm{p} 21^{\mathrm{CIP} 1}$, and p $27^{\mathrm{KIP} 1}$ protein levels and in cdk2-activity (Figures 4,5 , and not shown).

When freshly isolated CD $34^{+}$cells were cultured for 60 hours on PLL- or FN-coated dishes in the presence of low doses of cytokines, similar results were seen: $\mathrm{p} 27^{\mathrm{KIP} 1}$ levels were 1.5 -fold higher in the FN-adherent portion compared with FN-nonadherent portion, and 1.8-fold and 2.3-fold compared with PLL-adherent and PLL-nonadherent portions, respectively. Interestingly, the level of p27 ${ }^{\mathrm{KIP} 1}$ was 2.13 -fold higher in $\mathrm{CD} 34^{+}$cells cultured for 60 hours in FN-coated wells in the presence of low doses of cytokines compared with freshly isolated and uncultured CD $34^{+}$cells, even

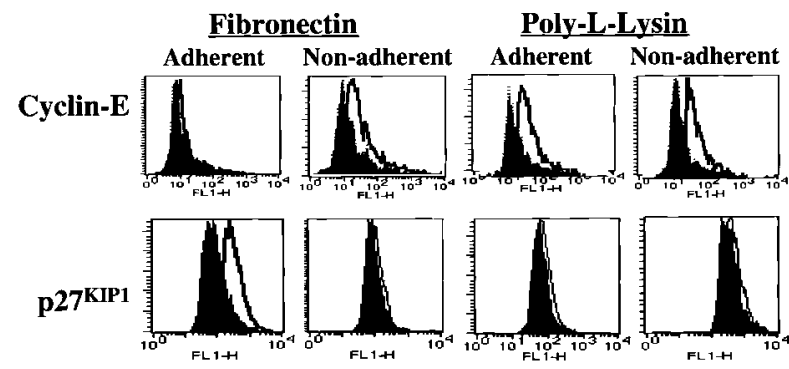

Figure 4. Adhesion to FN. Adhesion to FN leads to increased levels of p27KIP1 and decreased levels of cyclin-E. Mobilized blood CD $34^{+}$cells, cultured for 48 hours in serum-free medium with low-dose cytokines, were incubated with the activating anti- $\beta 1$-integrin antibody $8 \mathrm{~A} 2$ for 30 minutes at $37^{\circ} \mathrm{C}$ and plated in $\mathrm{PLL}$ - or FN-coated dishes for 12 to 16 hours. Adherent and nonadherent cells were collected separately. Cells were fixed, permeabilized, and incubated with antibodies directed at p27 KIP1 and cyclin-E (open histogram) or isotype control (closed histogram) antibody at room temperature for 30 minutes followed by FITC-conjugated goat antimouse immunoglobulin for 30 minutes in the dark. Cells were washed and resuspended in $50 \mu \mathrm{g} / \mathrm{mL}$ propidium iodide. Cells were analyzed on a FACS-Calibur flow cytometer with the use of CellQuest software. A representative example of 5 individual experiments is shown.

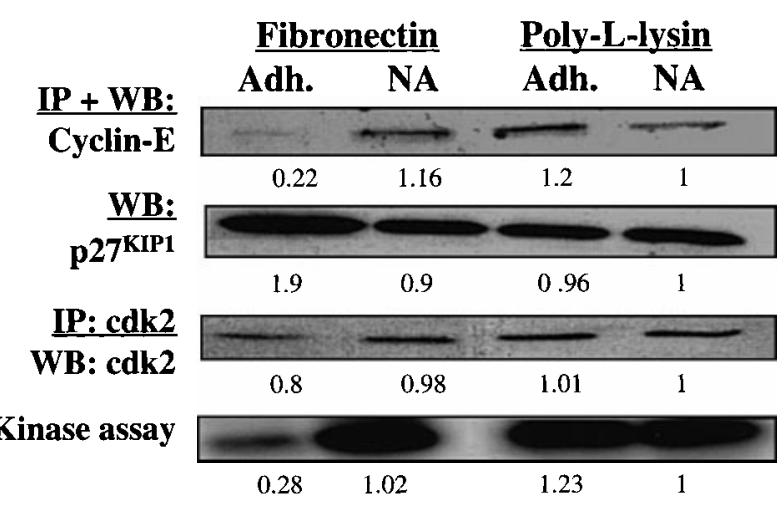

Figure 5. Adhesion to FN. Adhesion to FN is associated with increased levels of p2 $7^{\mathrm{KIP} 1}$ and decreased cdk2-kinase activity. Mobilized blood $\mathrm{CD} 34^{+}$cells cultured for 48 hours in serum-free medium with low-dose cytokines were incubated with 8A2, washed, and plated in PLL- or FN-coated dishes for 12 to 16 hours. Adherent (Adh) and nonadherent (NA) cells were collected separately, and cells were lysed. A representative example of 3 individual experiments is shown. For p2 $7^{\mathrm{KIP} 1}$, protein extracts were separated by SDS-PAGE, transferred onto nitrocellulose, and incubated with antibodies against $\mathrm{p} 27^{\mathrm{KIP} 1}$ and goat antimouse HRP-conjugated antibody. Cyclin-E was immunoprecipitated from protein-G-agarose beads. Immune complexes were separated by SDS-PAGE and blots probed with anti-cyclin-E antibodies and goat antimouse HRP-conjugated antibody. Protein bands were visualized with the use of the ECL detection system, and cdk2 was immunoprecipitated with the use of protein-G-agarose beads. The immune complexes were separated by SDS-PAGE, and blots were probed with anti-cdk2 antibodies and goat antimouse HRPconjugated antibody. Cdk2 activity was assayed by adding $5 \mu \mathrm{g}$ histone and $10 \mu \mathrm{Ci}$ $\left[{ }^{-}-{ }^{32} \mathrm{P}\right]$. Reaction products were resolved by SDS-PAGE, and the gel was exposed to $X$-ray film. Differences in protein levels were evaluated by scanning images with a GS-700 Imaging Densitometer and quantitated with the use of Molecular Analyst software. Relative protein levels/kinase activity values are shown below all lanes (PLL-nonadherent is arbitrarily 1 ).

though both populations contained only a small portion of cells in $S$ phase. Thus, contact with FN, rather than $\mathrm{G}_{0} / \mathrm{G}_{1}$ state of the cell, is associated with increased levels of $\mathrm{p} 27^{\mathrm{KIP} 1}$ (Figure 3).

\section{IL3 or SCF does not alter adhesion of CD34 ${ }^{+}$cells and CFC to FN but overrides P27 ${ }^{\mathrm{KIP} 1}$-mediated $\mathrm{G}_{1} / \mathrm{S}$ blockade following $\beta 1$-integrin engagement}

We next examined if supraphysiological concentrations of cytokines known to stimulate progenitor growth would affect integrinmediated functions. Cells were cultured for 48 to 72 hours in low-dose cytokine-containing medium to induce S-phase entry. Cells were then resuspended in serum-free medium either without cytokines or with $10 \mathrm{ng} / \mathrm{mL}$ IL3, GM-CSF, SCF, or Flt-3L. The portion of $\mathrm{CD}_{3} 4^{+}$cells or $\mathrm{CFC}$ that adhered to $\mathrm{FN}$ was similar when adhesion assays were done in the absence or presence of any of the following: IL3, GM-CSF, SCF, or Flt-3L (Table 1). In contrast to $\mathrm{CFC}$ cultured in contact with $\mathrm{FN}$ in the absence of

Table 1. Adhesion of CD $34^{+}$cells and CFC to FN in the presence or absence of supraphysiological concentrations of cytokines

\begin{tabular}{lcccc}
\hline Condition & $\begin{array}{c}\text { FN (CFC) } \\
(\mathrm{n}=2-6)\end{array}$ & $\begin{array}{c}\mathrm{FN}\left(\mathrm{CD} 34^{+}\right) \\
(\mathrm{n}=9)\end{array}$ & $\begin{array}{c}\text { PLL }(\mathrm{CFC}) \\
(\mathrm{n}=2-6)\end{array}$ & $\begin{array}{c}\text { PLL }\left(\mathrm{CD} 34^{+}\right) \\
(\mathrm{n}=9)\end{array}$ \\
\hline None & $18 \pm 4$ & $15 \pm 3$ & $62 \pm 8$ & $56 \pm 3$ \\
IL3 & $16 \pm 4$ & $14 \pm 2$ & $58 \pm 10$ & $49 \pm 6$ \\
GM-CSF & $15 \pm 4$ & - & $53 \pm 8$ & - \\
SCF & $21 \pm 4$ & $13 \pm 3$ & $66 \pm 12$ & $56 \pm 3$ \\
Flt3-L & $20 \pm 3$ & - & $60 \pm 8$ & - \\
\hline
\end{tabular}

Data are shown as mean \pm SEM. CFC indicates colony-forming cells; FN, fibronectin; PLL, poly-L-lysine; IL3, interleukin-3; GM-CSF, granulocyte-macrophagecolony stimulating factor; SCF, stem cell factor; and Flt3-L, fetal liver tyrosine kinase-3 ligand. 
Table 2. Percentage of CD34+ cells and CFC in S phase following coculture with FN in the presence or absence of supraphysiological concentrations of cytokines

\begin{tabular}{|c|c|c|c|c|}
\hline Condition & $\mathrm{FN}(\mathrm{CFC})$ & $\mathrm{FN}\left(\mathrm{CD} 34^{+}\right)$ & PLL (CFC) & $\operatorname{PLL}\left(C D 34^{+}\right)$ \\
\hline None & $3 \pm 2^{*}$ & $11.5 \pm 2^{*}$ & $35 \pm 3$ & $23 \pm 3.4$ \\
\hline IL3 & $28 \pm 5$ & $25 \pm 2.8$ & $30 \pm 5$ & $26.4 \pm 4$ \\
\hline GM-CSF & $27 \pm 6$ & - & $28 \pm 6$ & - \\
\hline SCF & $31 \pm 6$ & $23 \pm 3.5$ & $34 \pm 6$ & $23 \pm 2.9$ \\
\hline Flt3-L & $32 \pm 7$ & - & $29 \pm 7$ & - \\
\hline
\end{tabular}

Data are shown as mean \pm SEM. CFC indicates colony-forming cells; FN, fibronectin; PLL, poly-L-lysine; IL3, interleukin-3; GM-CSF, granulocyte-macrophagecolony stimulating factor; SCF, stem cell factor; and Flt3-L, fetal liver tyrosine kinase-3 ligand.

${ }^{*} P<.01$.

cytokines, contact with FN in the presence of $10 \mathrm{ng} / \mathrm{mL}$ IL3, GM-CSF, SCF, or Flt-3L prevented inhibition of $\mathrm{G}_{1} / \mathrm{S}$-phase progression of $\mathrm{CFC}$, and contact with FN in the presence of IL3 or SCF also prevented the $\mathrm{G}_{0} / \mathrm{G}_{1}$ blockade in CD34 ${ }^{+}$cells (Table 2).

We next analyzed the expression level and activity of cell cycle proteins in $\mathrm{FN}$-adherent or $\mathrm{FN}$-nonadherent cells in cultures supplemented with IL3 or SCF $(n=3)$. To increase the portion of FN-adherent cells, we added the activating anti- $\beta 1$-integrin antibody $8 \mathrm{~A} 2$. Except for an increase in the portion of adherent cells, no differences were seen in the proliferative status of $\mathrm{FN}$-adherent and FN-nonadherent cells or in the levels of cell cycle-associated proteins in the presence or absence of 8A2 (not shown). Levels of cyclin-E were higher in $\mathrm{CD} 34^{+}$cells adherent to $\mathrm{FN}$ in the presence of either IL3 (Figure 6) or SCF (data not shown) compared with $\mathrm{CD}^{2} 4^{+}$cells adherent to $\mathrm{FN}$ in the absence of cytokines. In contrast to cytokine-free assays, p2 $7^{\mathrm{KIP1}}$ levels were not elevated in CD $34^{+}$ cells adherent to FN in the presence of IL3 (Figure 6) or SCF (data not shown). Levels of the other cell cycle proteins, including PCNA, cyclin- $\mathrm{D}_{1+2+3}, \mathrm{p} 21^{\mathrm{CIP} 1}$, and $\mathrm{p} 16^{\mathrm{INK} 4 \mathrm{~A}}$, were similar in the presence or absence of IL3 or SCF (not shown). Immunoprecipitation and Western blot and kinase assays $(\mathrm{n}=3)$ confirmed that IL3 prevents the accumulation of $\mathrm{p} 27^{\mathrm{KIP1}}$ and allows activation of cdk2, even when $\mathrm{CD}_{3} 4^{+}$cells were adherent to FN (Figure 7).

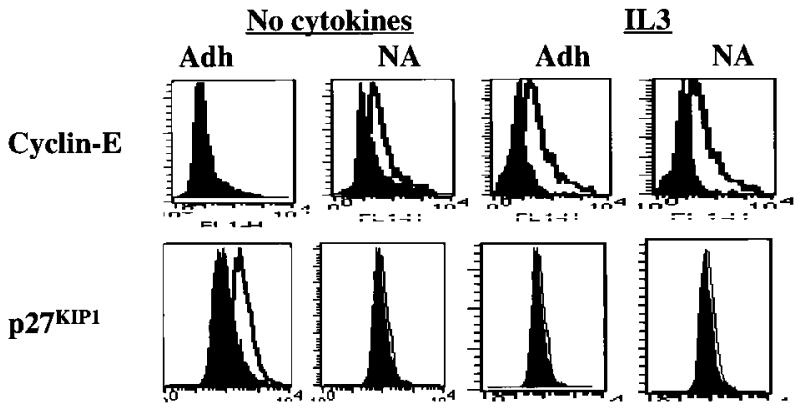

Figure 6. Presence of IL3 during the adhesion assay. Presence of IL3 during the adhesion assay prevents up-regulation of $27^{\mathrm{KIP} 1}$ and allows up-regulation of cyclin-E. Mobilized blood CD $34^{+}$cells cultured for 48 hours in serum-free medium with low-dose cytokines were incubated with $8 \mathrm{~A} 2$ and plated, with or without 10 $\mathrm{ng} / \mathrm{mL}$ IL3, in PLL- or FN-coated wells for 12 to 16 hours. Adherent and nonadherent cells were collected separately, fixed, permeabilized, washed, and incubated with antibodies directed at $\mathrm{p} 27^{\mathrm{KIP} 1}$ and cyclin-E (open histogram) or isotype control (closed histogram) at room temperature for 30 minutes, followed by FITC-conjugated goat antimouse immunoglobulin. A representative example of 3 individual experiments is shown. Adhesion to PLL in the presence or absence of IL3 did not affect the expression level of cyclin-E or p2 $7^{\text {KIP1 }}$ (not shown). However, up-regulation of p27 KIP1 and down-regulation of cyclin-E levels are prevented when IL3 is present during the adhesion assay.

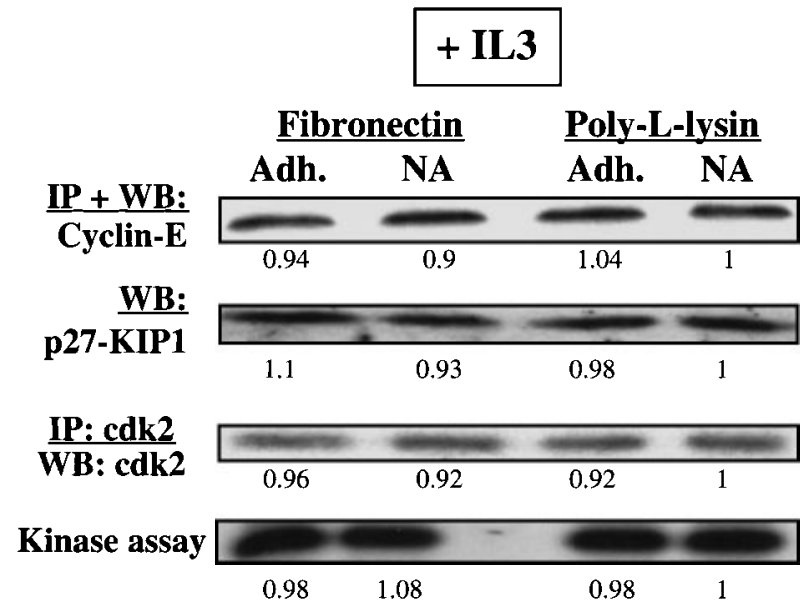

Figure 7. Presence of IL3 or SCF during the adhesion assay. Presence of IL3 or SCF during the adhesion assay prevents up-regulation of p27 KIP1 and inhibition of cdk2-kinase. Mobilized blood $\mathrm{CD}_{3} 4^{+}$cells cultured for 48 hours in serum-free medium with low-dose cytokines were incubated with $8 \mathrm{~A} 2$ and plated, with or without $10 \mathrm{ng} / \mathrm{mL} \mathrm{IL3}$, in PLL- or FN-coated dishes for 12 to 16 hours. Adherent and nonadherent cells were collected separately, and cells were lysed. Methods used to demonstrate presence and activity of $\mathrm{p} 27^{\mathrm{KIP} 1}$, cyclin-E, and cdk2-kinase activity are as described in legend to Figure 5. Differences in protein levels were evaluated by scanning images with a GS-700 Imaging Densitometer and quantitated with the use of Molecular Analyst software. A representative example of 2 individual experiments is shown. Relative protein levels/kinase activity values are shown below all lanes (PLL-nonadherent is arbitrarily 1 ).

\section{Discussion}

We still do not know which signals are responsible for the regulation of hematopoietic progenitor proliferation, quiescence, or differentiation. More than 30 hematopoietic cytokines and growth factors that increase or decrease progenitor proliferation and differentiation have been cloned and characterized. Although the molecular effect of these factors on hematopoietic cells has been extensively studied, it remains unclear how the combination of these factors regulates the hematopoietic process. In vivo hematopoiesis normally occurs in close proximity with BM stromal elements. Coculture of progenitors with BM stromal feeders in vitro inhibits progenitor proliferation through mechanisms that are as yet not understood. ${ }^{4-6,43,44}$ Progenitors, as well as cytokines, can bind specifically with ligands on cells and extracellular matrix present in the $\mathrm{BM},{ }^{1-3,45,46}$ resulting in the colocalization of progenitors at a specific stage of differentiation with a specific array of cytokines. ${ }^{47}$ This is thought to provide one level of regulation of growth and differentiation. There is also mounting evidence that contact interactions between progenitors and $\mathrm{BM}$ stromal ligands may be equally, or even more, important for the regulation of the hematopoietic process. Recent studies have shown that engagement of, for instance, selectins ${ }^{48}$ and mucins ${ }^{49,50}$ may profoundly affect progenitor survival and growth. Likewise, engagement of integrins may enhance progenitor survival in culture. ${ }^{51}$ We describe here how integrin engagement alters progenitor growth.

We used 2 experimental assays to investigate these questions. Almost all $\mathrm{CD}_{3}{ }^{+}$cells collected from the $\mathrm{PB}$ of individuals treated with G-CSF are in $\mathrm{G}_{0} / \mathrm{G}_{1}$. In 1 set of studies, we showed that FN coculture of PB CD $34^{+}$cells that are in $\mathrm{G}_{0} / \mathrm{G}_{1}$ prevents entry into $S$ phase compared with cells cocultured with PLL or BSA, suggesting that engagement of $\beta 1$-integrins prevents entry 
into cell cycle. This is consistent with what we have previously shown for steady-state marrow-derived $\mathrm{CD} 34^{+}$cells $^{4-7}$ and what we show here for $\mathrm{CD}_{3} 4^{+}$cells present in cultured (and hence proliferating) mobilized $\mathrm{PB} \mathrm{CD} 34^{+}$cell populations: when cocultured with FN, but not PLL, the portion of $\mathrm{CD} 34^{+}$cells in $\mathrm{S}$ phase declines. Using blocking monoclonal antibodies, we showed that induction of $\mathrm{G}_{1} / \mathrm{S}$ blockade by adhesion-receptor engagement in human hematopoietic progenitors is $\beta 1$-integrin specific: in contrast to $\beta 1$-integrins, engagement of other transmembrane adhesion receptors, such as $\mathrm{CD} 44,{ }^{7} \mathrm{CD} 34,{ }^{7}$ and $\mathrm{CD} 62 \mathrm{~L}$ (data shown here), did not affect the proportion of progenitors that is in $\mathrm{S}$ phase.

$\beta 1$-integrin-mediated block in $\mathrm{G}_{1} / \mathrm{S}$ transition in hematopoietic cells occurs in late $G_{1}$ and is associated with elevated levels of $\mathrm{p} 27^{\mathrm{KIP} 1}$ and inactivation of cyclin-E/cdk 2 complexes. Of interest is the fact that levels of $\mathrm{p} 27^{\mathrm{KIP} 1}$ were significantly less elevated in uncultured $\mathrm{CD}_{3} 4^{+}$cells selected fresh from mobilized PB than in $\mathrm{CD} 4^{+}$cells cultured for 60 hours with low concentrations of cytokines in contact with FN. This suggests strongly that elevation of $\mathrm{p} 27^{\mathrm{KIP} 1}$ is not merely a reflection of presence in $\mathrm{G}_{0} / \mathrm{G}_{1}$ status but is correlated with engagement of integrins.

This is in contrast to what has been described in the majority of other biological systems: engagement of integrins usually activates cyclin-D/cdk4 and cyclin-E/cdk2 or cyclin-A/cdk2 complexes leading to cell proliferation but not growth arrest. ${ }^{13-15,25-27}$ In contrast to the $\mathrm{CD} 34^{+}$cells studies here, those reports describe the effect on cell cycle proteins in cells that require adhesion for cell growth, such as fibroblasts, endothelial cells, and myocytes. A few examples have been described of adhesion-mediated $\mathrm{G}_{1}$-phase arrest mediated through mechanisms similar to what we show here for hematopoietic cells: growth arrest occurred late in $\mathrm{G}_{1}$ and was due to elevated levels of the "contact" cdki p27 KIP1, which inhibits cyclin-E/cdk2 kinase activity. ${ }^{52-55}$ When $\alpha 5 \beta 1-$ mediated adhesion of the FET colon carcinoma cell line to FN was prevented, FET cells were induced to proliferate. ${ }^{51}$ This was associated with activation of extracellular signal-regulated kinase- 1 and extracellular signal-regulated kinase-2 and significantly elevated levels of cdk4, phosphorylation of $\mathrm{Rb}$, and increased cyclin-A/cdk2 and cyclin-E/cdk2-associated kinase activity. Thus, as we show here for hematopoietic cells, $\alpha 5 \beta 1$ engagement in FET colon carcinoma cells suppresses cyclin-dependent kinase activity, leading to growth arrest. $\mathrm{G}_{1^{-}}$ phase growth arrest was also seen when arterial smooth muscle cells were cultured on polymerized type I collagen. ${ }^{53}$ This was associated with elevated levels of p27 $7^{\mathrm{KIP} 1}$ and $\mathrm{p} 21^{\mathrm{CIP} 1}$ and decreased cyclin-E-associated cdk2 kinase activity. In contrast, when cultured on monomer collagen, arterial smooth muscle cell proliferation was induced rather than growth arrest. Like FN-adherent human $\mathrm{CD}_{3} 4^{+}$cells, which are round even in the adherent state, arterial smooth muscle cells adherent to polymeric collagen adhere in a rounded state and do not spread. These results suggest that, like lateral association and ligand-binding-site occupation, ${ }^{10}$ cell shape may be an additional parameter that dictates the type of molecules recruited to focal adhesions and therefore the type of signal pathways that are activated or blocked. This is consistent with recent studies by Chen et $\mathrm{al}^{54}$ demonstrating that cell death is influenced not only by integrin engagement by a substrate but also by cell shape.

That cell-cell contact causes normal cells to stop proliferating has long been known in normal organ development. More recently it has become clear that such contact-mediated growth arrest is mediated by up-regulation of the cdki, p27 ${ }^{\mathrm{KIP} 1}, 56,57$ which inactivates cyclin-E/cdk2 and cyclin-A/cdk2 complexes. This is illus- trated in mutant $\mathrm{p} 27^{\mathrm{KIP} 1-/-}$ mice that display generalized increased body size and a significantly expanded hematopoietic progenitor pool. ${ }^{56,57}$ This appears to be consistent with our observation that cell-ECM interaction elevates levels of p27 ${ }^{\mathrm{KIP} 1}$ and inhibits $\mathrm{G}_{1} / \mathrm{S}$ progression of $\mathrm{CD} 34^{+}$progenitors. Regulation of $\mathrm{p} 27^{\mathrm{KIP} 1}$ levels is complex. ${ }^{58,59}$ Elevated levels can be due to increases in transcription, messenger RNA (mRNA) stabilization, or decreased protein degradation. Preliminary results from ribonucleotide protection assays (results not shown) suggest that the regulation of $\mathrm{p} 27^{\mathrm{KIP} 1}$ by integrin engagement on $\mathrm{CD} 34^{+}$cells may not be at the transcriptional level.

Finally, we found that integrin-mediated block in $\mathrm{G}_{1} / \mathrm{S}$ transition can be modulated when external conditions change: addition of supraphysiological concentrations of IL3 and GM-CSF, which bind to a common receptor in the hematopoietic receptor binding family, ${ }^{60}$ or SCF and Flt-3L, which signal via tyrosine kinase receptors, ${ }^{61}$ counteracts the adhesion-mediated block in $G_{1} / S$ progression. Recent studies from other groups have shown that IL3 and SCF activate protein kinase C (PKC) and tyrosine kinases that lead to enhanced adhesive capacity of $\beta 1$-integrins present on serum- and cytokine-starved CD $34^{+}$cells and CFC. ${ }^{28-30}$ In contrast, we show that supraphysiological concentrations of IL3, GM-CSF, SCF, or Flt-3L did not affect adhesion of human CFC or CD34 ${ }^{+}$ cells when they were maintained under physiological conditions. Our results are consistent with studies from Strobel et $\mathrm{al}^{32}$ and Schofield et al $^{31}$ demonstrating that supraphysiological concentrations of cytokines do not alter the adhesive function of integrins under serum/cytokine-replete conditions. Even though adhesion of $\mathrm{CD} 34^{+}$cells to FN was not affected by the presence of IL3 or SCF, presence of these supraphysiological concentrations of cytokines prevented adhesion-mediated increased p27 KIP1 levels and prevented adhesion-mediated inhibition of cdk2 activity. Signal pathways activated by cytokine stimulation have been extensively studied. Stimulation of either hematopoietic or tyrosine kinase receptors leads to recruitment and activation of signal and adaptor proteins and to activation of signal pathways that are also recruited/activated by integrin stimulation. Like integrin engagement, stimulation of c-kit leads to phosphorylation of paxillin and CrkL, activation of PI3-kinase, Ras, and MAPK. ${ }^{60,61}$ Likewise, IL-3 phosphorylates CrkL and paxillin and activates PI3-kinase and MAPK, molecules known to be recruited to and activated in focal adhesions. ${ }^{62-68}$ Thus, significant overlap exists between signal pathways activated following cell adhesion or stimulation with cytokines. Since the mechanism(s) that underlie adhesion-mediated signaling in hematopoietic cells are unknown, we can only speculate how the combined activation of integrin and cytokine receptors affects hematopoietic cell growth. However, the characterization of conditions that allow adhesion without cell cycle arrest and conditions that induce adhesion with cell cycle arrest should prove useful in deciphering the signal pathways that are activated by engagement of integrins leading to growth arrest of human hematopoietic progenitors.

In conclusion, we demonstrate that cell cycle arrest and reduced proliferation of $\mathrm{CD} 4^{+}$cells, which are adherent to $\mathrm{FN}$ under physiological cytokine conditions, are mediated by the cdki, p2 $7^{\mathrm{KIP} 1}$. However, costimulation of FN-adherent progenitors with certain growth-promoting cytokines overrides this integrindependent elevation of p27 ${ }^{\mathrm{KIP} 1}$ and allows S-phase entry of CD34 ${ }^{+}$ cells. Future studies will identify the molecular mechanisms underlying the reversible inhibition of entry in $\mathrm{S}$ phase mediated by changes in $\mathrm{p} 27^{\mathrm{KIP} 1}$. 
From www.bloodjournal.org at kuleuven on October 6, 2010. For personal use only.

\section{References}

1. Coulombel L, Auffray I, Gaugler MH, Rosemblatt $M$. Expression and function of integrins on hematopoietic progenitor cells. Acta Haematol. 1997; 97:13-21.

2. Simmons PJ, Levesque JP, Zannettino AC. Adhesion molecules in haemopoiesis. Baillieres Clin Haematol. 1997;10:485-505.

3. Verfaillie CM, McCarthy JB, McGlave PB. Differentiation of primitive human multipotent hematopoietic progenitors into single lineage clonogenic progenitors is accompanied by alterations in their interaction with FN. J Exp Med. 1991;174:693-703.

4. Verfaillie CM. Direct contact between progenitors and stroma is not required for human in vitro hematopoiesis. Blood. 1992;79:2821-2826.

5. Hurley RW, McCarthy JB, Verfaillie CM. Direct adhesion to bone marrow stroma via FN receptors inhibits hematopoietic progenitor proliferation. J Clin Invest. 1995;96:511-519.

6. Verfaillie CM, Catanzarro P. Development of a novel single LTC-IC proliferation assay that can determine the fate of LTC-IC over time. Leukemia. 1996;10:498-504.

7. Hurley R, McCarthy JB, Verfaillie CM. Monoclona antibody crosslinking of the alpha 4 or beta 1 integrin inhibits committed clonogenic hematopoietic progenitor proliferation. Exp Hematol. 1997;25: 321-328.

8. Aota S, Yamada KM. Integrin functions and signal transduction. Adv Exp Med Biol. 1997;400B:669682.

9. Shattil SJ, Kashiwagi H, Pampori N. Integrin signaling: the platelet paradigm. Blood. 1998;91: 2645-2657.

10. Yamada KM. Integrin signaling. Matrix Biol. 1997; 16:137-141.

11. Malik RK. Regulation of apoptosis by integrin receptors. J Pediatr Hematol Oncol. 1997;19:541 545.

12. Frisch SM, Ruoslahti E. Integrins and anoikis. Curr Opin Cell Biol. 1997;9:701-706.

13. Giancotti FG. Integrin signaling: specificity and control of cell survival and cell cycle progression. Curr Opin Cell Biol. 1997;9:691-700.

14. Howe A, Aplin AE, Alahari SK, Juliano RL. Integrin signaling and cell growth control. Curr Opin Cell Biol. 1998;10:220-231.

15. Juliano R. Cooperation between soluble factors and integrin-mediated cell anchorage in the control of cell growth and differentiation. Bioessays. 1996;18:911-917.

16. Guan JL. Focal adhesion kinase in integrin signaling. Matrix Biol. 1997;16:195-200.

17. Avraham $\mathrm{S}$, Avraham H. Characterization of the novel focal adhesion kinase RAFTK in hematopoietic cells. Leuk Lymphoma. 1997;27:247-256.

18. Hannigan GE. Dedhar S. Protein kinase mediators of integrin signal transduction. J Mol Med. 1997;75:35-44

19. Malik RK, Parsons JT. Integrin-mediated signaling in normal and malignant cells: a role of protein tyrosine kinases. Biochem Biophys Acta. 1996; 1287:73-76

20. Petruzzelli L, Takami M, Herrera R. Adhesion through the interaction of lymphocyte functionassociated antigen-1 with intracellular adhesion molecule-1 induces tyrosine phosphorylation of p130cas and its association with c-Crkll. J Biol Chem. 1996;271:7796-7801.

21. Petruzzelli L, Takami M, Herrera R, et al. Integrinmediated signal transduction linked to Ras pathway by GRB2 binding to focal adhesion kinase. Nature. 1994;372:786-791.

22. Manie SN, Beck AR, Astier A, et al. Involvement of p130(Cas) and p105(HEF1), a novel Cas-like docking protein, in a cytoskeleton-dependent sig- naling pathway initiated by ligation of integrin or antigen receptor on human B cells. J Biol Chem. 1997;272:4230-4236.

23. Shimizu Y, Hunt SW III. Regulating integrin-mediated adhesion: one more function for PI 3-kinase? Immunol Today. 1996;17:565-573.

24. Yurochko AD, Liu DY, Eierman D, Haskill S. Integrins as a primary signal transduction molecule regulating monocyte immediate-early gene induction. Proc Natl Acad Sci U S A. 1992;89:90349038.

25. Zhu X, Ohtsubo M, Bohmer RM, Roberts JM, Assoian RK. Adhesion-dependent cell cycle progression linked to the expression of cyclin D1, activation of cyclin E-cdk2, and phosphorylation of the retinoblastoma protein. J Cell Biol. 1996; 133:391-403.

26. Fang F, Orend G, Watanabe N, Hunter T, Ruoslahti E. Dependence of cyclin E-CDK2 kinase activity on cell anchorage. Science. 1996;271: 499-502.

27. Shulze A, Zerfass-Thome K, Berges J, Middendorp S, Jansen-Durr P, Henglein B. Anchoragedependent transcription of the cyclin A gene. Mol Cell Biol. 1996;16:4632-4638.

28. Levesque JP, Haylock DN, Simmons PJ. Cytokine regulation of proliferation and cell adhesion are correlated events in human CD34+ hematopoietic progenitors. Blood. 1996;88:1168-1176.

29. Levesque JP, Leavesley DI, Niutta S, Vadas M, Simmons PJ. Cytokines increase human hematopoietic cell adhesiveness by activation of very late antigen (VLA)-4 and VLA-5 integrins. J Exp Med. 1995;181:1805-1815.

30. Kovach NL, Lin N, Yednock T, Harlan JM, Broudy VC. Stem cell factor modulates avidity of alpha 4 beta 1 and alpha 5 beta 1 integrins expressed on hematopoietic cell lines. Blood. 1995;85:159-167.

31. Schofield KP, Rushton G, Humphries MJ, Dexter TM, Gallagher JT. Influence of interleukin-3 and other growth factors on alpha4beta1 integrin-mediated adhesion and migration of human hematopoietic progenitor cells. Blood. 1997;90:18581866.

32. Strobel ES, Mobest D, von Kleist S, et al. Adhesion and migration are differentially regulated in hematopoietic progenitor cells by cytokines and extracellular matrix. Blood. 1997;90:3524-3532.

33. Simmons PJ, Haylock DN. Use of hematopoietic growth factors for in vitro expansion of precursor cell populations. Curr Opin Hematol. 1995;2:189195

34. Schofield KP, Humphries MJ, de Wynter E, Testa N, Gallagher JT. The effect of alpha4 beta1integrin binding sequences of $\mathrm{FN}$ on growth of cells from human hematopoietic progenitors. Blood. 1998;91:3230-3238.

35. Lundell BI, McCarthy JB, Kovach NL, Verfaillie CM. Activation-dependent alpha5beta1 integrinmediated adhesion to fibronectin decreases proliferation of chronic myelogenous leukemia progenitors and K562 cells. Blood. 1996;87: 2450-2458.

36. Prosper F, McCarthy JD, Stroncek D, Verfaillie $\mathrm{CM}$. Mobilization and homing of peripheral blood progenitors is related to reversible downregulation of $\alpha 4 \beta \in \tau \alpha 1$ integrin expression and function. J Clin Invest. 1998;101:2456-2467.

37. Gupta P, McCarthy JB, Verfaillie CM. Stromal fibroblast heparan sulfate is required for cytokine mediated ex vivo maintenance of human longterm culture-initiating cells. Blood. 1996;87:32293236.

38. Vindelov LL, Christensen IJ. A review of techniques and results obtained in one laboratory by an integrated system of methods designed for routine clinical flow cytometric DNA analysis. Cytometry. 1990;11:753-770.

39. Zhao RC, Mclvor RS, Griffin JD, Verfaillie CM Gene therapy for chronic myelogenous leukemia $(\mathrm{CML})$ : a retroviral vector that renders hematopoietic progenitors methotrexate-resistant and CML progenitors functionally normal and nontumorigenic in vivo. Blood. 1997;90:4687-4698.

40. Ladd AC, Pyatt R, Gothot A, et al. Orderly process of sequential cytokine stimulation is required for activation and maximal proliferation of primitive human bone marrow CD34 + hematopoietic progenitor cells residing in $\mathrm{G}_{0}$. Blood. 1997;90: 658-668.

41. Lemoli RM, Tafuri A, Fortuna A, et al. Cycling status of CD34+ cells mobilized into peripheral blood of healthy donors by recombinant human granulocyte colony-stimulating factor. Blood. 1997;89:1189-1196.

42. Williams CD, Linch DC, Watts MJ, Thomas NS. Characterization of cell cycle status and E2F complexes in mobilized CD34+ cells before and after cytokine stimulation. Blood. 1997;90:194203.

43. Cashman J, Eaves AC, Eaves CJ. Regulated proliferation of primitive hematopoietic progenitor cells in long-term human marrow cultures. Blood. 1985;66:1002-1005.

44. Eaves CJ, Cashman JD, Kay RJ, et al. Mechanisms that regulate the cell cycle status of very primitive hematopoietic cells in long-term human marrow cultures. II. Analysis of positive and negative regulators produced by stromal cells within the adherent layer. Blood. 1991;78:110-117.

45. Gupta P, Oegema TR, Verfaillie CM. Differences in the LTC-IC maintaining capacity of stromal cells correlates with patterns of sulfation of their heparan sulfate glycosaminoglycans. In Press. Blood.

46. Bruno E, Luikart SD, Long MW, Hoffman R. Mar row-derived heparan sulfate proteoglycan mediates the adhesion of hematopoietic progenitor cells to cytokines. Exp Hematol. 1995;23:12121217.

47. Schofield R. The stem cell system. Biomed Pharmacother. 1983;37:375-380.

48. Zannettino AC, Berndt MC, Butcher C, Butcher EC, Vadas MA, Simmons PJ. Primitive human hematopoietic progenitors adhere to P-selectin (CD62P). Blood. 1995;85:3466-3477.

49. Watt SM, Buhring HJ, Rappold I, et al. CD164, a novel sialomucin on CD34 $(+)$ and erythroid subsets, is located on human chromosome 6q21. Blood. 1998;92:849-866.

50. Bazil V, Brandt J, Chen S, et al. A monoclonal antibody recognizing CD43 (leukosialin) initiates apoptosis of human hematopoietic progenitor cells but not stem cells. Blood. 1996;87:12721281.

51. Moritz T, Dutt $P$, Xiao X, et al. Fibronectin improves transduction of reconstituting hematopoietic stem cells by retroviral vectors: evidence of direct viral binding to chymotryptic carboxy-terminal fragments. Blood. 1996;88:855-862.

52. Gong J, Ko TC, Brattain MG. Disruption of FN binding to the alpha 5 beta 1 integrin stimulates the expression of cyclin-dependent kinases and DNA synthesis through activation of extracellular signal-regulated kinase. J Biol Chem. 1998;273: 1662-1669.

53. Koyama H, Raines EW, Bornfeldt KE, Roberts JM, Ross R. Fibrillar collagen inhibits arterial smooth muscle proliferation through regulation of Cdk2 inhibitors. Cell. 1996;87:1069-1078.

54. Chen CS, Mrksich M, Huang S, Whitesides GM, Ingber DE. Geometric control of cell life and death. Science. 1997;276:1425-1428. 
From www.bloodjournal.org at kuleuven on October 6, 2010. For personal use only.

55. Kato A, Takahashi H, Takahashi Y, Matsushime H. Inactivation of the cyclin D-dependent kinase in the rat fibroblast cell line, $3 Y 1$, induced by contact inhibition. J Biol Chem. 1997;272:8065-8070.

56. Nakayama K, Ishida N, Shirane M, et al. Mice lacking p27(Kip1) display increased body size, multiple organ hyperplasia, retinal dysplasia, and pituitary tumors. Cell. 1996;85:707-720.

57. Johnson D, Frame MC, Wake JA. Expression of the $\mathrm{v}$-Src oncoprotein in fibroblasts disrupts normal regulation of the CDK inhibitor p27 and inhibits quiescence. Oncogene. 1998;16:2017-2028.

58. Flinch IL, Ana S, Mantra N, Bah JJ, Moroccan E. Changes in E2F complexes containing retinoblastoma protein family members and increased cyclin-dependent kinase inhibitor activities during terminal differentiation of cardiomyocytes. J Mol Cell Cardiol. 1998;30:563-578.

59. Vlach J, Hennecke S, Amati B. Phosphorylationdependent degradation of the cyclin-dependent kinase inhibitor p27. EMBO J. 1997;16:53345344.
60. Bagley CJ, Woodcock JM, Stomski FC, Lopez AF. The structural and functional basis of cytokine receptor activation: lessons from the common beta subunit of the granulocyte-macrophage colony-stimulating factor, interleukin-3 (IL-3), and IL-5 receptors. Blood. 1997;89:1471-1482.

61. Lyman SD, Jacobsen SE. C-kit ligand and FIt3 ligand: stem/progenitor cell factors with overlapping yet distinct activities. Blood. 1998;91:11011134.

62. Takahira H, Gotoh A, Ritchie A, Broxmeyer HE. Steel factor enhances integrin-mediated tyrosine phosphorylation of focal adhesion kinase (pp125FAK) and paxillin. Blood. 1997;89:15741584.

63. Sattler M, Salgia R, Shrikhande G, et al. Stee factor induces tyrosine phosphorylation of CRKL and binding of CRKL to a complex containing Ckit, phosphatidylinositol 3-kinase, and p120(CBL). J Biol Chem. 1997;272:10,248-10,253.

64. Hara T, Miyajima A. Function and signal transduc- tion mediated by the interleukin 3 receptor system in hematopoiesis. Stem Cells. 1996:14:605 618

65. Anderson SM, Burton EA, Koch BL. Phosphorylation of $\mathrm{Cbl}$ following stimulation with interleukin-3 and its association with Grb2, Fyn, and phosphatidylinositol 3-kinase. J Biol Chem. 1997;272:739745.

66. Barber DL, Mason JM, Fukazawa T, et al. Erythropoietin and interleukin-3 activate tyrosine phosphorylation of $\mathrm{CBL}$ and association with CRK adaptor proteins. Blood. 1997;89:3166-3174.

67. Salgia R, Li JL, Lo SH, et al. Molecular cloning of human paxillin, a focal adhesion protein phosphorylated by P210BCR/ABL. J Biol Chem. 1995; 270:5039-5047.

68. O'Farrell AM, Ichihara M, Mui AL, Miyajima A. Signaling pathways activated in a unique mast cell line where interleukin-3 supports survival and stem cell factor is required for a proliferative response. Blood. 1996;87:3655-3668. 